Vol 12, Issue 4, 2019

\title{
DESIGN, FORMULATION, AND EVALUATION OF SOLID DISPERSION TABLETS OF POORLY WATER-SOLUBLE ANTIDIABETIC DRUG USING NATURAL POLYMER
}

\author{
SUDIPTA DAS*, PRIYANKA MANDAL \\ Department of Pharmaceutics, Netaji Subhas Chandra Bose Institute of Pharmacy, Chakdaha, Nadia, West Bengal, India. \\ Email: sudiptapharmacy6@gmail.com
}

Received: 26 January 2019, Revised and Accepted: 5 March 2019

\section{ABSTRACT}

Objective: The objective of the present study was to formulate the solid dispersion (SD) of poorly water-soluble drug glimepiride and the development of the tablets of prepared SD of glimepiride using natural and synthetic polymers.

Methods: The SD of glimepiride was to prepare using fusion method. The tablets were prepared by wet granulation method using synthetic polymer such as HPMC and natural polymer gellan gum.

Results: The granules were evaluated by determining the angle of repose $\left(23.70 \pm 0.761\right.$ to $\left.29.21 \pm 0.127^{\circ}\right)$, bulk density, tapped density, Hausner ratio, and Carr's index. It shows satisfactory results. The tablets were subjected to the measurement of hardness $\left(3.9 \pm 0.08\right.$ to $\left.4.6 \pm 0.04 \mathrm{~kg} / \mathrm{cm}^{2}\right)$, friability $(0.22 \pm 0.004$ to $0.40 \pm 0.005 \%)$, and in vitro release studied. Release study of pure drug was performed. In the release study, SD of glimepiride tablets with gellan gum gives considerably good result compared to HPMC.

Conclusion: From the results, it was shown that dissolution rate of pure glimepiride was very slow. When the glimepiride was prepared in SD form, then the dissolution rate was very fast. The tablets of the SD of glimepiride were prepared and release study was shown depending on various quantities of HPMC and gellan gum used. Therefore, the long term stability study is required for future development of this formulation.

Keywords: Solid dispersion, Glimepiride, HPMC, Gellan gum.

(C) 2019 The Authors. Published by Innovare Academic Sciences Pvt Ltd. This is an open access article under the CC BY license (http://creativecommons. org/licenses/by/4. 0/) DOI: http://dx.doi.org/10.22159/ajpcr.2019.v12i4.32035

\section{INTRODUCTION}

Diabetes mellitus (DM) is a one of the major concerns across the globe. It is a group of metabolic disorder characterized by abnormal high blood glucose level occurred due to low insulin level or defect in insulin secretion. DM is differentiated into two major types, i.e., Type I (insulindependent diabetes) and Type II (insulin-independent diabetes). In Type I diabetes, destruction of beta cells of pancreatic islets leads to the low level of insulin and so the resistance of glucose level in blood is decreased. Type II diabetes is a result of the lower response of glucoreceptor of beta cells or reduced number of insulin or relative deficiency of insulin due to large secretion of hyperglycemia hormones (glucagon, etc.) or obesity. For the treatment of DM, many drugs are in use, the most effective one is insulin, but its main drawback is that it must be given by injection. To overcome these drawbacks, oral hypoglycemic drugs came into use [1,2].

Glimepiride is the newest second-generation sulfonylurea and is sometimes classified as the third generation sulfonylurea. It is found to have significant action in lowering off blood glucose level in Type II diabetes. Glimepiride has shown to act for long period than glipizide. FDA also approved its use in combination with insulin and metformin. Its administration is quite difficult as it is poorly soluble in aqueous medium and slow dissolution rate, which leads to poor bioavailability $[3,4]$.

Solid dispersion (SD) is one of the techniques to increase the solubility and dissolution rate of poorly soluble drugs. This technique is shown to have successfully improved the solubility and dissolution rate of glimepiride. Therefore, our main objective is to prepare SD of glimepiride with urea by fusion method and formulated as tablets along with HPMC or gellan gum. Then, the formulated tablets are evaluated by various tests to observe its dissolution rate $[5,6]$.

\section{MATERIALS AND METHODS}

Materials

Glimepiride and gellan gum are purchased from Yerrow Chem Pvt., Ltd. HPMC, magnesium stearate, and talc were purchased from Loba Chemie Pvt., Ltd. (Mumbai). Mark Speciality Pvt. Ltd. (Mumbai) supplied microcrystalline cellulose (MCC).

\section{Methods}

Preparation of SD by fusion method

In fusion method, urea is first melted in water bath with gradual increase in temperature until it completely melts. Now, drug is added in the melted urea with constant stirring and leaves this mixture to cool at room temperature. The ratio of drug and urea taken is $1: 1$. The mixture was dried, crushed, pulverized, and passed through sieve number \#60 and stored in desiccators [7-9].

\section{Preparation of tablets}

SD of glimepiride tablets was prepared by wet granulation method using single punch tablet compression machine. Glimepiride, HPMC or gellan gum, and MCC mixed properly. The binder solution was added slowly so that the granules are formed uniformly. After drying, talc and magnesium stearate added with granules. The granules are placed in a tablet compression machine to obtain number of tablets of uniform size and shape [10]. The various compositions of glimepiride SD tablets shown on the Table 1 .

\section{Characterization of granules flow characteristics}

Bulk density

A known quantity $(\mathrm{m})$ of granules was poured into the measuring cylinder carefully. The granules were leveled without compacting, if necessary and read the unsettled apparent volume $(\mathrm{V})$, to the nearest 
graduated unit. The bulk density was calculated and expressed in gm per $\mathrm{ml}$, by the formula $\mathrm{m} / \mathrm{V}[11]$.

\section{Tapped density}

A known quantity of granules was taken in a measuring cylinder and tapped on mechanical tapping apparatus for $5 \mathrm{~min}$. The initial and final volumes were noted [11]

Tapped density=Weight of granules/Final volume after tapping

\section{Angle of repose}

The frictional forces in a loose powder or granules can be measured by the angle of repose. This is the maximum angle possible between the surface of a pile of powder or granules and the horizontal plane. This is done by funnel method [12]. The value of angle of repose is calculated using the following formula:

$\tan \theta=\mathrm{h} / \mathrm{r}$

$\theta=\tan ^{-1}(\mathrm{~h} / \mathrm{r})$

Where, $\theta=$ Angle of repose, $\mathrm{h}=$ Height of the heap, and $\mathrm{r}=$ Radius of the heap

\section{Compressibility index and Hausner ratio}

The compressibility index and the closely related Hausner ratio have become the simple, fast, and popular methods of predicting granules

Table 1: Composition of glimepiride SD tablets

\begin{tabular}{lllllll}
\hline Ingredients & F1 & F2 & F3 & F4 & F5 & F6 \\
\hline Glimepiride (SD) & 100 & 100 & 100 & 100 & 100 & 100 \\
HPMC & 80 & 100 & 120 & - & - & - \\
Gellan gum & - & - & - & 80 & 100 & 120 \\
MCC & 170 & 150 & 130 & 170 & 150 & 130 \\
Magnesium stearate & 5 & 5 & 5 & 5 & 5 & 5 \\
Talc & 5 & 5 & 5 & 5 & 5 & 5 \\
\hline
\end{tabular}

SD: Solid dispersion flow characteristics. The compressibility index and Hausner ratio were determined by measuring both the bulk density and tapped density of granules [13].

Compressibility index=(Tapped density-Bulk density)/Tapped density $\times 100$

Hausner ratio= Tapped density/bulk density

\section{Evaluation of tablets}

Hardness test

Hardness of the tablets was measured by Monsanto hardness tester [14].

\section{Friability test}

Friability of the tablets was measured by Roche friabilator [15].

\section{Dissolution}

The dissolution test was performed by USP dissolution test apparatus Type II containing $900 \mathrm{ml}$ of 7.8 phosphate buffer for $3 \mathrm{~h}$ at $50 \mathrm{rpm}[16,17]$.

\section{RESULTS AND DISCUSSION}

The results of bulk density, tapped density, angle of repose, Hausner ratio, and compressibility index are shown in Table 2 . The hardness and friability of the prepared glimepiride SD tablets are shown in Table 3. The granules were evaluated by determining the angle of repose (23.70 $\pm 0.761-29.21 \pm 0.127)$, bulk density $(0.32 \pm 0.008-0.47 \pm 0.018)$, tapped density $(0.44 \pm 0.006-0.59 \pm 0.001)$, Hausner ratio (1.25 $\pm 0.020-1.42 \pm 0.017)$, and Carr's index (11.42 $\pm 0.09-15.80 \pm 0.07)$. It showed satisfactory results. The tablets were subjected to measurement of hardness $\left(3.9 \pm 0.08-4.6 \pm 0.04 \mathrm{~kg} / \mathrm{cm}^{2}\right)$ and friability $(0.22 \pm 0.004-0.40 \pm 0.005 \%)$. It also showed satisfactory results.

The dissolution rate of pure glimepiride was very slow $(24.67 \%$ at $3 \mathrm{~h}$ ). When the glimepiride was prepared in SD form, then the dissolution rate was very fast. The tablets of SD of glimepiride

Table 2: Precompression evaluation

\begin{tabular}{|c|c|c|c|c|c|}
\hline Formulation code & Bulk density $\left(\mathrm{Kg} / \mathrm{cm}^{3}\right)$ & Tapped density $\left(\mathrm{Kg} / \mathrm{cm}^{3}\right)$ & Carr's index & Hauser's ratio & Angle of Repose ( ${ }^{\circ}$ ) \\
\hline F1 & $0.32 \pm 0.008$ & $0.44 \pm 0.006$ & $11.72 \pm 0.06$ & $1.37 \pm 0.025$ & $25.62 \pm 0.435$ \\
\hline $\mathrm{F} 2$ & $0.40 \pm 0.012$ & $0.57 \pm 0.002$ & $12.80 \pm 0.04$ & $1.42 \pm 0.017$ & $29.21 \pm 0.127$ \\
\hline F3 & $0.32 \pm 0.009$ & $0.42 \pm 0.007$ & $15.80 \pm 0.07$ & $1.31 \pm 0.022$ & $26.58 \pm 0.402$ \\
\hline F4 & $0.44 \pm 0.015$ & $0.56 \pm 0.003$ & $11.42 \pm 0.09$ & $1.27 \pm 0.023$ & $24.94 \pm 0.533$ \\
\hline F5 & $0.45 \pm 0.016$ & $0.57 \pm 0.003$ & $14.05 \pm 0.03$ & $1.26 \pm 0.018$ & $24.42 \pm 0.424$ \\
\hline F6 & $0.47 \pm 0.018$ & $0.59 \pm 0.001$ & $13.33 \pm 0.04$ & $1.25 \pm 0.020$ & $23.70 \pm 0.761$ \\
\hline
\end{tabular}

All values are expressed as Mean $\pm(t \times S E M), n=3$

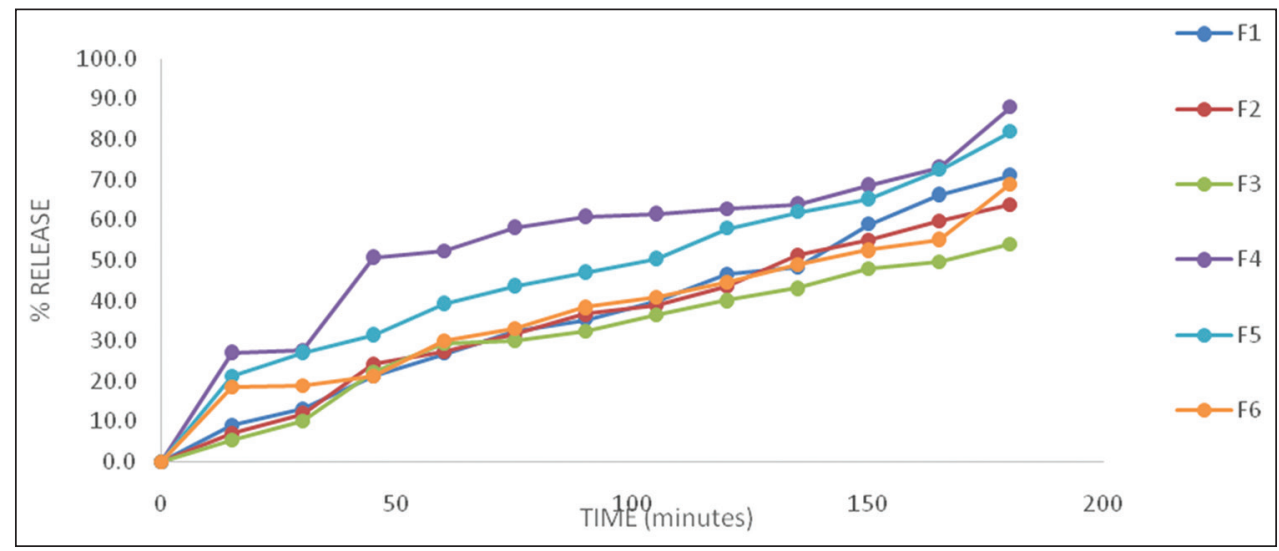

Fig. 1: Release profile of glimepiride solid dispersion tablets 
Table 3: Postcompression evaluation

\begin{tabular}{lll}
\hline Formulation & Hardness $\left(\mathbf{k g} / \mathbf{c m}^{2}\right)$ & Friability (\%) \\
\hline F1 & $4.1 \pm 0.10$ & $0.32 \pm 0.007$ \\
F2 & $4.0 \pm 0.11$ & $0.25 \pm 0.006$ \\
F3 & $3.9 \pm 0.08$ & $0.22 \pm 0.004$ \\
F4 & $5.6 \pm 0.05$ & $0.40 \pm 0.005$ \\
F5 & $4.6 \pm 0.04$ & $0.32 \pm 0.003$ \\
F6 & $4.4 \pm 0.09$ & $0.33 \pm 0.006$ \\
\hline
\end{tabular}

All values are expressed as Mean $\pm(t \times S E M), n=3$

were prepared and release study was shown depending on various quantities of HPMC and gellan gum used. The release studies of formulations (F4, F5, and F6) of glimepiride SD tablets using gellan gum were found $87.9315,81.8762$, and $68.8681 \%$, respectively, at $3 \mathrm{~h}$. Release pattern of tablets using gellan gum is very satisfactory. The gellan gum is natural polymer, so it is added advantages to prepare tablets using this gum. The results are shown in Fig 1. Therefore, the long term stability study is required for future development of this formulation.

\section{CONCLUSION}

The dissolution rate of pure glimepiride was very slow. When the glimepiride was prepared in SD form, then the dissolution rate was very fast. The tablets of the SD of glimepiride were prepared and release study was shown depending on various quantities of HPMC and gellan gum used. The release of glimepiride SD tablets using gellan gum was better compare to tablets prepared with HPMC. As the dissolution rate of glimepiride SD tablets increased, then bioavailability also increased. Therefore, the long term stability study is required for future development of this formulation.

\section{ACKNOWLEDGMENT}

The authors would like to thank principal and authority of Netaji Subhas Chandra Bose Institute of Pharmacy, Chakdaha, Nadia - 741 222, West Bengal, India, for providing the necessary facilities to perform the present study.

\section{AUTHORS' CONTRIBUTIONS}

Each author is equally contributed.

\section{CONFLICTS OF INTEREST}

The authors confirm that this article content has no conflicts of interest.

\section{REFERENCES}

1. Tripathi K. Essentials of Medical Pharmacology. $7^{\text {th }}$ ed. New Delhi: Jaypee Brother's Medical Publishers (P) Ltd.; 2013.

2. Alberti KG, Zimmet PZ. Definition, diagnosis and classification of diabetes mellitus and its complications. Part 1: Diagnosis and classification of diabetes mellitus provisional report of a WHO consultation. Diabet Med 1998;15:539-53.

3. McCall AL. Clinical review of glimepiride. Expert Opin Pharmacother 2001;2:699-713.

4. Ammar HO, Salama HA, Ghorab M, Mahmoud AA. Formulation and biological evaluation of glimepiride-cyclodextrin-polymer systems. Int J Pharm 2006;309:129-38.

5. Emara LH, Badr RM, Abd Elbary A. Improving the dissolution and bioavailability of nifedipine using solid dispersions and solubilizers. Drug Develop Ind Pharm 2002;28:795-807.

6. Sunitha N. Formulation and evaluation of aceclofenac solid dispersions for dissolution rate enhancement. Int J Pharm Sci Drug Res 2010;2:146-50.

7. Sridhar I, Doshi A, Joshi B, Wankhede V, Doshi J. Solid dispersions: An approach to enhance the solubility of poorly water-soluble drugs. J Sci Innov Res 2013;2:685-94.

8. Serajuddin AT. Solid dispersion of poorly water-soluble drugs: Early promises, subsequent problems, and recent breakthroughs. J Pharm Sci 1999;88:1058-66.

9. Shamsuddin, Fazil M, Ansari SH, Ali J. Development and evaluation of solid dispersion of spironolactone using fusion method. Int J Pharm Investig 2016;6:63-8.

10. Iqbal Z, Babar A, Ashraf MH. Controlled-release naproxen using micronized ethyl cellulose by wet-granulation and solid-dispersion method. Drug Develop Ind Pharm 2002;28:129-34.

11. Gupta A, Kataria MK, Bilandi A. Formulation and evaluation of solid dispersion of glipizide for solubility and dissolution rate enhancement. Int J Pharm Drug Anal 2014;2:74-87.

12. Das S, Naskar S. A Practical Book on Physical Pharmaceutics-II. 1st ed. Pune, India: Everest Publishing House; 2019.

13. Das S, Samanta A, Sekhar DH. Formulation, in-vitro release kinetics and stability interpretation of sustained release tablets of metformin hydrochloride. Int J Pharm Pharm Sci 2015;7:418-22.

14. Nag D, Das S, Samanta A. Formulation and evaluation of immediate release tablets of isoniazid and pyridoxine hydrochloride. World J Pharm Pharm Sci 2015;4:1726-40.

15. Das AS, Das S, Samanta A. Formulation and evaluation of controlled release floating capsules of ciprofloxacin HCL. Der Pharm Sin 2013;4:72-5

16. Venkatarao M, Vidyadhara S, Sandeep D. Formulation and evaluation of telmisartan solid dispersions using Entada scandens seed starch and poloxamer-188 as telmisartan. Asian J Pharm Clin Res 2018;11:474-81.

17. Yadav S, Veena M, Srinivas M. Solid dispersion technique to enhance the solubility and dissolution rate of aripiprazole by fusion method. Int J Pharm Pharmaceutical Sci 2016;8:187-92. 